\title{
Explicit Author Reference in Research Articles in Linguistics in English and Croatian
}

\author{
Ivana Bašić ${ }^{*}$, Snježana Veselica-Majhut \\ Department of English, Faculty of Humanities and Social Sciences, Zagreb University, Croatia
}

Copyright $(2016$ by authors, all rights reserved. Authors agree that this article remains permanently open access under the terms of the Creative Commons Attribution License 4.0 International License

\begin{abstract}
The paper investigates linguistic patterns of direct author reference in research papers in linguistics in English and Croatian. All research papers communicate empirically proven, verifiable findings of conducted scientific research, but the rhetorical practices of various disciplinary communities vary greatly in terms of what they consider appropriate ways of "academic persuasion", that is ways of communicating their research activities and findings in a persuasive way. The presented research is based on the assumption that, apart from differences in the rhetorical conventions of various disciplinary communities, there are also differences between the conventions of particular scientific communities within the same discipline. This assumption is tested by means of text analysis of two corpora of linguistics research articles written in English and Croatian. The use of the first person singular and plural is analyzed as a direct signal of writer presence in research articles, with a view to tracing down conventionalized rhetorical practices within a single discipline in two discrete scientific communities. In addition to the analysis of the preferred patterns of direct author reference, the text analysis is aimed at uncovering and comparing discourse functions of direct author reference in the two corpora. Interviews with members of the Croatian linguistics scientific community are conducted in order to find out in what ways those authors acquired the conventions of academic writing in linguistics, how much they emphasize their own authorial role in their research papers and what communicative effects they wish to achieve with the chosen rhetorical strategies. The contribution of this research is to shed light on the differences between the rhetorical practices of academic writing in linguistics in the two studied communities.
\end{abstract}

Keywords Explicit Author Reference, First Person Pronouns, Research Articles, Discourse Functions

\section{Introduction}

This paper subscribes to the current approaches to academic discourse which view academic writing as a social activity whose primary aim is to construct "knowledge" in a particular discipline [1], [2] [3], [4]. We focus on the genre of the journal research article (RA), the typical means for academics to communicate research findings and seek validation for their claims.

All research papers communicate empirically proven, verifiable research findings, but the rhetorical practices of various disciplinary communities vary greatly in terms of what they consider appropriate ways of reporting their research activities and findings in a persuasive way. In an increasingly globalized academic community today, one of the greatest challenges is to find the way to tackle the main paradox of academic writing - the fact that authors need to present themselves both as "disciplinary servants" and "persuasive originators"[1: p.224]. Depending on the epistemological beliefs of the disciplinary community they belong to and the writing traditions of their academic community, writers will make different rhetorical choices [1], [2], [5], [6], [7], [8], [9], [10]. Thus, research paper authors will either choose to make their writing impersonal and their authorial presence less visible or they will make it personal, with a strong authorial voice.

This paper focuses on explicit author reference in linguistics RAs in English and Croatian. Our research is based on the assumption that, apart from differences in the rhetorical conventions of various disciplinary communities (set in the larger context of the traditional dichotomy between "hard" and "soft" disciplines), there are also differences between the conventions of particular (national) scientific communities within the same discipline. In order to test this assumption we conducted textual analysis of two corpora of linguistics RAs taken from journals in English and Croatian and number of interviews with members of the Croatian linguistics academic community.

The textual analysis examines the use of the first person singular and plural as a direct signal of author presence in the RA. The primary aim of the textual analysis is to see whether the Croatian and English authors differ in the preferred patterns of author referencing. Further, the aim of the textual analysis is to uncover what discourse functions are realized 
by using the first person singular and plural in each corpus and what style of writing (personal or impersonal) is prevalent in each corpus. Interviews with Croatian authors of RAs in linguistics are carried out in order to gain insights into their perceptions of conventions governing the use of personal pronouns in scientific writing.

The fact that this research is limited to the use of first person singular and plural references as an authorial rhetorical choice in RAs does not mean that we believe that this is the only, or the most important, of the rhetorical choices that the authors of RAs make. The limited scope is due to practical concerns; namely, the fact that this paper is part of a larger project - a wider-scope research into the conventions and preferred authorial rhetorical choices in English and Croatian RAs, which is still ongoing.

While the use of English for academic purposes has been widely studied, Croatian for academic purposes has not been the subject of such intensive studying. No comparative research on the rhetorical practices of academic writing in English and Croatian has been carried out so far. Therefore, the contribution of this research is to shed light on the differences between the rhetorical practices of RA writing in the field of linguistics in the two disciplinary communities: the Croatian and the international English linguistics community.

\section{Personal Pronouns in Research Articles}

The use of first person singular and plural pronouns in RAs in English has been studied intensively in the context of self representation in writing and the need to determine to what extent scholars can explicitly refer to themselves and their individual contribution in their RA texts.

Ivanic and Simpson [11]claim that the use of the personal style in English research articles is the reflection of a heightening awareness of the author's role in writing, while Vasilleva [5] relates it to the Anglo-Saxon idea of "authorial responsibility".

According to Hyland [1], in RAs in English first person pronouns (FPP) are more frequently used in social sciences and the humanities (the "soft" fields) than in the natural sciences and technical disciplines (the "hard" fields), which is the result of both the nature of the research process (argumentative versus experimental) and the epistemological traditions of the disciplines. For example, in the "soft" fields FPP are used much more frequently with the function of promoting the author of the RA, which is not common practice in the "hard" fields. [1]

We believe that the authors' rhetorical choices in terms of the more personalized or more detached style of writing in RAs (reflected, among other choices, in the use of either the first person references or the passive/impersonal structures) depends both on the disciplinary cultural conventions, but also on the cultural conventions of individual national disciplinary communities. In order to test this hypothesis we have conducted our research on two corpora - a corpus of linguistics RAs in English and a corpus in Croatian, complemented with interviews with members of Croatian linguistics disciplinary community.

In the following section, we shall introduce two fundamental concepts necessary for understanding the role of FPP in RAs - the concepts of semantic reference and discourse function.

\subsection{Semantic References and Discourse Functions of First Person Singular and Plural Pronouns}

With regard to their semantic reference, FPP can be exclusive or inclusive. First person singular (FPSg) pronouns and determiners in RAs in English $(I, m e, m y)$ are always exclusive in their reference, i.e. they refer only to the author of the text. First person plural (FPPl) pronouns and determiners in RAs in English (we, us, our) can be either exclusive (referring to the author of the text (authorial "we") or to the author and coauthors), or inclusive (referring to the author and the constructed readers of the text (fellow researchers, peers) or to the entire disciplinary community).

The discourse function of FPP in RAs is defined as the function that the sentence with the personal pronoun has in the immediate context of the RA. The discourse function reflects the communicative intention of the author of the RA [6: p.130] Some examples of the discourse functions of FPP in RAs include: acknowledging funding bodies, institutions and individuals who contributed to the study in some ways, expressing intention, organizing the text and guiding the reader through the argument, recounting experimental procedure and methodology, making a claim and emphasizing one's own contribution. Personal pronouns in RAs are frequently multifunctional. For instance, they can at the same time act as discourse guides, promote the researcher and construct solidarity with the readership [8: p.363].

Examining the functions of personal pronouns can help us reveal how the writers of RAs construct the relationship with their readers and their discourse community [6].

Several authors have offered functional taxonomies of FPP, trying to determine the relationship between the discourse function of the pronoun and the degree of authorial presence [2], [7], [8], [12].

\subsection{The Communicative Effects of Using the First Person in RAs}

If we relate the possible communicative effects of FPP in RAs to the principles of the politeness theory [13], some uses of "I" and "we" may be considered low-risk instances of authorial intervention. Conversely, high-risk discourse functions are potentially face-threatening acts, which result in the feeling of strong authorial presence and expose the 
author to criticism [8]. Tang and John [7] claim that the most threatening functional categories of the first person, which they call "I" as Opinion-Holder and "I" as Originator, normally use exclusive rather than inclusive pronouns.

Lower-risk discourse functions in RAs achieve positive politeness by creating an atmosphere of dialogue, community and interaction. They are generally realized by means of inclusive pronouns. Using the inclusive "we" authors of RAs construct the reader in the text with whom they engage in imaginary dialogue [1],[14].

Asserting that the primary aim of any writer of RAs is to persuade the readers to see things their way, Latour [15] identifies the category of the ostensibly inclusive "we", which serves as a rhetorical means of persuasion, a means of achieving greater rhetorical effectiveness, covertly instructing the reader how to interpret the data.

\section{Methodology}

In order to meet the aims of the research we conducted a textual analysis of two corpora, a corpus of English and a corpus of Croatian RAs. We also conducted interviews with ten members of the Croatian linguistics disciplinary community in order to gain insights into their perceptions of conventions governing the use of personal pronouns in scientific writing.

\subsection{The Textual Corpora}

\subsubsection{Compilation of the Textual Corpora}

In the compilation of the corpora we applied systematic random sampling. Applying the criteria of quality (peer-reviewed, high-impact journals in linguistics) and scope (we wanted to ensure adequate representation and range for various segments of the discipline), we selected three linguistics journals written in English and three in Croatian. Thus, the English corpus comprises RAs published in Applied Linguistics (AL), Cognitive Linguistics (CL) and Language (L). The Croatian corpus comprises the following journals: Suvremena lingvistika (SL), Jezik (J) and Language as Information, The Proceedings of the annual conference of the Croatian Society for Applied Linguistics (HDPL). We included all single -author articles published in one issue of the above journals, thus ending up with the total number of 16 RAs in English and 20 RAs in Croatian.

\subsubsection{Methodology of Textual Analysis}

In English, direct author reference is mainly realized through the use of personal pronouns (the first person singular and plural), whereas in Croatian it is signaled through first person singular and plural inflected verbs. In the English corpus we first identified the instances of the use of FPP and possessive determiners in all their forms in the singular and plural (I, me, my; we, us, our) and recorded the number of occurrences for each RA. In the Croatian corpus we identified all the instances of inflected first person singular and plural verbs, as well as the occurrences of first person singular and plural pronouns and determiners. We recorded the number of occurrences of the first person singular and plural for each RA. Next, we determined the semantic reference (inclusive/exclusive) and the discourse function for each occurrence of the first person in both corpora. The findings of the quantitative analysis are presented in Tables 1,2 and 3. The qualitative textual analysis uncovers the links between the different discourse functions and the particular type of the first person marker used in each of the two corpora.

\subsection{Interviews}

\subsubsection{Aims and Methodology}

We conducted ten semi-structured interviews. The specific aims of interviews were to find out in what ways those authors acquired the conventions of academic writing in linguistics and how much they emphasize their own authorial role in their research papers. The following criteria were applied in the selection of interviewees: all the authors of the RAs from our Croatian corpus who could be reached and who agreed to take part in the research were interviewed. We also interviewed two editors of Croatian linguistics journals in order to get the editorial perspective on the use of the personal form in RAs. Most of our interviewees are specialists in the modern languages (English, French, Italian, Croatian), and one is a phonetician. All of them publish both in Croatian and other languages (English, Italian, French) and all read RAs in English.

The format of semi-structured interviews is useful in this type of research, as it enables the researcher to let participants offer their views and opinions freely and without too much interference by the interviewer. The interviews were conducted and recorded in Croatian, and transcribed. Their relevant segments were translated to English.

The interviewees were asked to state their field of expertise and their years of experience in publishing RAs. They were then asked whether they had had formal instruction or guidance in academic writing, the writing of RAs in particular. There followed a set of open-ended questions aimed at finding out whether the interviewees believed there were any clear conventions in Croatian concerning the author's choice between the impersonal or personal form in RAs. We asked the participants to explain how they themselves decided what perspective to use and what their attitude was towards the use of first person forms in RAs. The interviewees were also asked whether the conventions concerning the choice between the personal or impersonal form differed in various languages and research communities and whether they themselves behaved differently as authors when they wrote in another language. 


\section{Findings and Discussion}

\subsection{Quantitative Findings and Discussion}

\subsubsection{Quantitative Data on the Use of First Person References}

Table 1. The overall number of occurrences in English and Croatian corpora

\begin{tabular}{|c|c|c|c|c|}
\hline & $\begin{array}{c}\text { 1st person } \\
\text { singular } \\
\text { total }\end{array}$ & $\begin{array}{c}\text { 1st person } \\
\text { plural } \\
\text { total }\end{array}$ & $\begin{array}{c}\text { 1st ps.Pl. } \\
\text { exclusive }\end{array}$ & $\begin{array}{c}\text { 1st ps.Pl. } \\
\text { inclusive }\end{array}$ \\
\hline $\begin{array}{c}\text { English } \\
\text { corpus }\end{array}$ & 221 & 181 & 5 & 176 \\
\hline $\begin{array}{c}\text { Croatian } \\
\text { corpus }\end{array}$ & 31 & 243 & 121 & 122 \\
\hline
\end{tabular}

As we can see from Table 1, in the English corpus FPSg references are considerably more frequently used than in the Croatian corpus (221 vs. 31). As for the use of FPPl references, in the Croatian corpus inclusive and exclusive references of the FPPl pronoun are equally present. On the other hand, we may perceive a clear preference for inclusive reference in the English corpus.

As can be observed in Table 2, there are virtually no uses of exclusive first person plural in the English corpus. Other than that, there are no features that are common to all articles. Rather, individual articles show the author's preference for personal forms, either the singular (RA 11, RA 16) or plural (RA 10), or their avoidance of the use of personal pronouns (RAs 4, 5, 6, 13). Judging from the data, the preference for either the personal or impersonal perspective does not seem to be the result of editorial policy, but rather the individual author's choice.

As Table 3 shows, the RAs in the Croatian corpus indicate the authors' general preference for the FPPl and avoidance of the FPSg, with RA 20 being markedly different in that respect. RAs 1, 2, 14, 18 exhibit the authors' strong preference for impersonal forms.

Again, as in the English corpus, the decision on whether to use the personal or impersonal form does not seem to be dictated by the journals' editorial policy.

Table 2. The number of occurrences in the English corpus by journal.

\begin{tabular}{|c|c|c|c|c|c|c|c|c|c|c|c|c|c|c|c|c|}
\hline Journal & \multicolumn{5}{|c|}{ Applied Linguistics } & \multicolumn{4}{c|}{ Cognitive Linguistics } & \multicolumn{5}{c|}{ Language } \\
\hline RA & 1 & 2 & 3 & 4 & 5 & 6 & 7 & 8 & 9 & 10 & 11 & 12 & 13 & 14 & 15 & 16 \\
\hline $\begin{array}{c}\text { 1st p.sg. } \\
\text { total }\end{array}$ & 6 & 6 & 13 & - & - & - & 10 & 20 & 2 & 7 & 36 & 2 & - & 23 & 48 & 48 \\
\hline $\begin{array}{c}1 \text { st p.pl. } \\
\text { total }\end{array}$ & 5 & 9 & 9 & - & - & 4 & 10 & 15 & 4 & 48 & 7 & 13 & 1 & 18 & 30 & 7 \\
\hline Incl. & 5 & 6 & 9 & - & - & 4 & 10 & 15 & 3 & 48 & 7 & 13 & 1 & 18 & 30 & 7 \\
\hline Excl. & - & 3 & - & - & - & - & - & - & 1 & - & 1 & - & - & - & - & - \\
\hline
\end{tabular}

Table 3. The number of occurrences in the Croatian corpus by journal.

\begin{tabular}{|c|c|c|c|c|c|c|c|c|c|c|c|c|c|c|c|c|c|c|c|c|}
\hline & \multicolumn{8}{|c|}{ HDPL } & \multicolumn{6}{|c|}{ Suvremena lingvistika } & \multicolumn{6}{|c|}{ Jezik } \\
\hline RA & 1 & 2 & 3 & 4 & 5 & 6 & 7 & 8 & 9 & 10 & 11 & 12 & 13 & 14 & 15 & 16 & 17 & 18 & 19 & 20 \\
\hline $\begin{array}{c}1 \mathrm{st} \\
\text { p.sg. } \\
\text { total }\end{array}$ & - & - & - & - & 5 & - & - & - & - & - & - & - & - & - & 2 & 3 & 4 & 2 & - & 15 \\
\hline $\begin{array}{c}1 \mathrm{st} \\
\text { p.pl. } \\
\text { total }\end{array}$ & 2 & - & 5 & 13 & 16 & 13 & 39 & 16 & 17 & 16 & 11 & 18 & 30 & - & 10 & 2 & 5 & - & 8 & 22 \\
\hline Incl. & 1 & - & 3 & 2 & 16 & 6 & 14 & 5 & 8 & 16 & - & 4 & 12 & - & 9 & 1 & 5 & - & - & 20 \\
\hline Excl. & 1 & - & 2 & 11 & - & 7 & 25 & 11 & 9 & - & 11 & 14 & 18 & - & 1 & 1 & - & - & 7 & 2 \\
\hline
\end{tabular}




\subsubsection{Qualitative Findings and Discussion}

The FPSg occurs in the English corpus in sentences with various discourse functions, both higher and lower risk ones. Most occurrences of FPPl pronouns in the English corpus are inclusive. They are predominantly used in lower-risk discourse functions, aiming to create an atmosphere of positive politeness. Very frequently FPP are used multifunctionally, for instance to announce the author's intention and to stress personal contribution or to create solidarity with the reader and seek acceptance for the author's claims.

The discourse functions of FPP in the corpus are directly related to the part of the research article in which they appear (introduction, aims, methods, data analysis, conclusion) and their distribution is regular and predictable. In the introduction sections, for instance, it is customary for authors to announce their intentions and aims, but also to point to their own contribution and make commitments. This is what Swales [16] refers to as "creating a research space". The example below illustrates how the author uses the FPSg to that end:

In Gries (2006a), I studied the verb to run... This unexpected phenomenon stimulated the exploration reported on in this paper. More specifically, I explore to what degree... In this paper, I therefore investigate this specific kind of... I discuss two case studies...

As I will show below, both case studies show...

\section{$(11, \mathrm{CL})$}

In another example, the author uses the FPSg to announce and commit herself to her aims and inclusive FPPl to exhibit familiarity with the accepted disciplinary understandings, to refer the reader to what has been said before, but also to make the reader see things her way and accept her reasoning and argumentation as viable:

My aim is to further investigate Krifka's claim... and to demonstrate the role of visual attention....

We know that in the case of alternating verbs, the ditransitive construction is preferred over the dative construction when......

We have seen that non-alternating verbs more freely appeared in the dative... (recall Table 2).

We also need to know how stable the probability and relative confidence levels are across corpora...

$(10, \mathrm{CL})$

As we can see from the two examples above, it is not the first person singular or plural per se that is used as a means of persuasion, resulting in the communicative effect of persuading the reader to accept the claims and propositions expressed in the sentence. Rather, it is the combination of the discourse function and the pronoun used that creates a persuasive effect. Some discourse functions, such as recounting experimental procedures, simply do not require persuasion, while others, such as arguing a point or contrasting one's view with somebody else's, are in their very nature persuasive endeavours. A more persuasive effect in those discourse functions can be achieved more or less overtly. In the example quoted above (10, CL), for instance, we may argue that the (ostensibly) inclusive "we" is used as a powerful, though less overt, rhetorical means of persuasion; namely, by using the inclusive "we" the author intends to make the reader feel that they are an active participant in the process of reasoning, which will presumably make the reader more inclined to accepting the reasoning as justified.

We should also note that the RAs in the English corpus in which the use of personal pronouns is avoided are authored by non-native English speakers (RA 4 and 5 by Spanish linguists and RA 6 by a Japanese linguist). In those RAs the authors consistently use passives or active structures with a metonymic subject ("this article", "the present study") instead of FPP. We may, therefore, suggest that these authors' decision to use impersonal forms might be governed by the presumed conventions of their native disciplinary communities in which a major part of the authors' professional life takes place. Apart from that, a significant factor might be the nature of the subject matter studied and the kind of methodology used to investigate it. Some sub-disciplines in linguistics and some subject matters will require a more experimental approach, while others will be more argumentative, and this will undoubtedly have an impact on the rhetorical strategies used in the research article (the authors of all five RAs from Language are American, but RAs 12 and 13 are experimental, whereas 15 and 16 are argumentative, "philosophical" RAs).

In the Croatian corpus the FPPl occurs in all the discourse functions where in English the FPSg occurs. Some of those functions are lower-risk (recounting the experimental procedure and methodology, explaining intentions and aims), while others are higher-risk (taking a stand and argumenting one's own position, emphasizing one's own contribution).

As in the English corpus, the discourse functions of the first person in the corpus are directly related to the part of the RA in which they appear and their distribution is regular and predictable.

The example below illustrates the use of exclusive FPP1 (authorial "we") in the discourse functions of recounting the procedure, argumenting the author's reasoning and making a claim, and the use of inclusive FPPl as a multifunctional discourse device for creating positive politeness by treating the reader as equal and at the same time seeking acceptance for the author's claims and asking the reader to see things in the same way as the author does. As far as the communicative effect of these authorial choices is concerned, we may argue that the inclusive "we" in the last sentence has been used with the intention of persuading the reader to see things the author's way, and that its communicative effect indeed is persuasive:

Sukladno tome kao mjerilo prijelaznosti uzeli smo prisutnost drugoga i trećega aktanta....,

(Consequently, we took the presence of the second and third actor to be a signal of transitivity...) 
Obrazložit ćemo našu odluku da obilježje prijelaznosti ne proširujemo na glagole koji....

(We shall explain our decision not to treat as transitive those verbs that....)

Nismo se priklonili ni Tesniereovim stajalištima....

(We didn't abide by Tesniere's view that...)

Zagledamo li se pak u povijest francuskoga jezika, vidjet ćemo da obilježje prijelaznosti nije stabilno.

To nam pokazuje da....

(If we look into the history of the French language, we shall see that transitivity is not a stable category in verbs. That shows us.....

\section{(7, HDPL)}

In another example, the author uses exclusive FPPl in the high-risk functions of making a claim, disagreeing with other authors and pointing to her own contribution:

Babby (1980) pristaje uz tezu da... S time se ne slažemo te djelomično pristajemo uz Perlmuttera i Moorea (1999), koji tvrde ...

Babby (1980) accepts the thesis that...

(We do not agree with this and partly support Perlmutter and Moore's (1999) view that....).

Iako se Babbyjev (1980) rad smatra jednim od prijelomnih...., mislimo da griješi kada....

(...) pa smo nabrajanjem u više izvora (...) došli do ovih glagola:...

(Although Babby's (1980) paper is considered one of the seminal works..., we believe he is mistaken to...(...), so by using several sources (...) we have come up with this list of verbs:...)

\section{$(12, \mathrm{SL})$}

In the Croatian corpus the first person singular is used markedly less frequently than the FPPl and extremely rarely in comparison to the English corpus. There are no examples in the Croatian corpus where authors use only the FPSg in their texts. The authors who choose the personal perspective tend to use the FPPl, with occasional occurrences of the FPSg, usually in the introduction and the discussion sections. It is worth noting that the author of RA 20, which has the highest number of occurrences of the FPSg, is an esteemed senior member of the Croatian linguistic disciplinary community, whereas the author of RA 5 is not actually a member of the Croatian linguistics community since he lives and works abroad. All these factors might be relevant in accounting for these authors' authorial perspectives.

In the example below, the author uses the FPSg to point to his contribution and to express an opinion. In the conclusion section, however, he uses the ostensibly inclusive FPPl multifunctionally, to remind the reader of the aim of the paper and to seek acknowledgement for his contribution:

Tim dvama ograničenjima koja navode Silić/Pranjković (ib.) dodajem još jedno:....

(I shall add two other restrictions to those singled out by Silić/Pranjković (ib.):......)

Ta ograničenja upućuju po mom mišljenju na to da ....
(In my view, these two restrictions indicate that...)

U ovom smo članku pokušali...

(In this paper we have tried to...)

$(15, \mathrm{~J})$

In the following example, the author moves between the first person singular in the introduction section, where he announces his aims and commits himself to meeting them, and exclusive first person plural in the data section, which is used multifunctionally to create a feeling of dialogue with the reader and make the reader accept his reasoning as valid:

$\mathrm{U}$ ovome radu namjera mi je prikazati...

(In this paper I intend to show...)

Usporedbom.... pokušat ću objasniti....

(I will try to explain ... by comparing...)

Pogledajmo kako su tri različite funkcije upućivanja riješene u tri dvojezična rječnika:... Ocijenimo li važnijim korisniku ponuditi prijevod riječi koju traži,...

(Let us look at how the three different functions of directing aare delat with in three bilingual dictionaries...

If we deem it relevant to offer the user the translation of the word he is looking up,...)

Ako pak želimo naznačiti važnost opisa....

(If, on the other hand, we wish to signal the importance of defining...)

(5, HDPL)

In the example below, the author uses the first person singular in the introductory section in the discourse function of explaining his reasoning and procedure and announcing to the reader what the text will focus on:

Zbog ekonomičnosti i stilske raznolikosti rabim katkada samo naziv hrvatski jezik, i zato raspravu o nazivu književni/standardni/normirani ovom prilikom možemo izostaviti.

(For reasons of economy and stylistic variation I sometimes use only the term Croatian language, and therefore we shall presently skip the discussion on the terms literary/standard/norm-governed)

U ovom raspravljanju mislim i na bošnjački i crnogorski književni jezik, ali se na njih izričito mnogo ne osvrćem..)

(In this discussion I refer to Bosnian and Montenegran literary language, but I do not deal with them explicitly...)

Za prihvaćanje književnoga jezika kao posebnoga idioma mogu se spomenuti mnogi djelatnici, ali ja bih se ovdje zaustavio na slavonskim piscima.

(In terms of accepting the literary language as a special idiom many individuals could be mentioned, but I shall stop here at Slavonian writers.)

$(20, \mathrm{~J})$

\subsubsection{The Conclusions of the Textual Analysis of the Corpora}

As we have pointed out, in the Croatian corpus the first person singular is used far more rarely than in the English corpus. In the Croatian corpus, the predominant authorial choice is either the first person plural, both exclusive and 
inclusive, or impersonal and passive forms. The authors who prefer the personal style tend to use exclusive first person plural (authorial "we") to refer to themselves. In the English corpus the prevalent strategy is using the first person singular and inclusive first person plural. Exclusive first person plural for one author (authorial "we") is close to non-existent in the English corpus. The use of the first person singular is not necessarily related to higher-risk discourse functions or face-threatening acts. On the contrary, in both corpora it occurs very frequently in lower-risk discourse functions such as acknowledging other people's or institutions' contributions to the research, explaining the experimental procedure and methodology or announcing aims and intentions. However, the instances of higher-risk discourse functions in the English corpus, functions such as making a claim, stressing one's individual contribution, challenging widely held disciplinary opinions and opposing other researchers' views are generally cast in the first person singular form. As opposed to that, higher-risk discourse functions in the Croatian corpus tend to be framed in the first person plural form. The first person singular, in its rare occurrences in the corpus, tends to be used in lower-risk discourse functions. Therefore, the English first person singular (which is by its nature exclusive in reference) and the Croatian exclusive first person plural which refers to one author seem to be functional equivalents in the higher-risk discourse functions in the RAs in the corpus.

In both corpora, the choice between a personal or impersonal style of writing clearly depends on the individual author. The individual texts of the RAs in both corpora tend to be quite homogenous in the choice of either personal or impersonal authorial perspective, but no such homogeneity or regularity is found among the RAs taken from the same journal or the RAs in English as opposed to those in Croatian. We may, therefore, conclude that the journals in our corpus do not have a firm editorial policy regarding the choice of authorial perspective and that this choice is left to the authors themselves. The authors of the RAs in our corpus seem to prefer either the personal or impersonal perspective and use the chosen perspective quite consistently throughout the text of the RA. In the RAs in the English corpus, the authors' native disciplinary community's culture seems to be a relevant factor in the choice of authorial perspective; more precisely, there is sufficient evidence to hypothesize that non-native authors abide by the presumed conventions of the disciplinary community in which they were formed as professionals even when they write in another language, in this case in English. In both corpora, however, the rhetorical strategies used in the individual RAs seem to reflect not only the presumed conventions of the disciplinary community in which the author actively participates but also various individual authorial personalities or personas that the authors deliberately construct by using different rhetorical strategies.

\subsection{Findings from Interviews and Discussion}

The aim of the interviews was to gather the data on the interviewees' perception of conventions which govern the choice between the impersonal or personal forms in RAs, on their attitudes towards these two styles of writing and their preferred authorial choices, and on their awareness of the possible differences in these conventions between various research communities.

Most of our interviewees claim to prefer impersonal forms and tend to have very strong attitudes in that respect. Their answers reflect an attitude which relates the use of the impersonal form to greater objectivity and the rules of scientific discourse:

"I always go for the impersonal form and I avoid myself as the subject, as well as my own, subjective impressions. I always tell my students that this kind of personalization might be ok for to school essays, but at the academic level you have to create some sense of distance and objectivity. I believe it is more appropriate in academic discourse to exclude yourself as a person. “(V.J., English Department)

"I try to use impersonal constructions; if it is a research paper it shouldn't have a subjective tone - the researcher is present implicitly, there's no need to emphasize their role..... it seems to me that is precisely the key point in scientific discourse - impersonality.“(V.D., Italian Department)

Other interviewees claim to fluctuate between impersonal forms and authorial „we“ but all of them state that they deliberately avoid ,I“:

"It seems to me that I mostly use the first person plural, which is customary in the Francophone scientific community. My writing, even in Croatian is greatly influenced by conventions in French.” (D.D.B., French Department)

"I use passive and „we“ with equal frequency." (Z.J., Croatian Department)

"Sometimes I can't decide, the passive tends to sound awkward in Croatian, so I go for a mix of the first person plural and passives.“(V.M., Phonetics Department)

"I sometimes use the first person plural, but never the first person singular." (V.D., Italian Department)

Comparing the texts from the corpus to the authors' claims about their preferred style of writing, we found a high degree of congruity between the authors' perception of their behaviour and their actual behaviour, which further supports our belief that the choice of perspective in the RA is a conscious and deliberate authorial decision.

Concerning the awareness of the conventions of using personal and impersonal forms in RAs, most of our interviewees believe there is a convention in Croatian not to use the first person pronoun in research articles, but one interviewee believes it depends on the author:

“... passive structures and the plural are used with roughly the same frequency, the singular is avoided.... because there is a convention that it is rude to write in the first person. (V.M., Phonetics Department) 
"Always, without fail, in the text I refer to myself as "we", even if I am the only author. I stick to the convention that it is better to disguise myself, to refer to myself as "we." (I.Z., English Department)

"In Croatian there are no firm conventions, it very much depends on the author." (V.D., Italian Department)

As far as formal education and guidance in academic writing generally and RA writing in particular is concerned, our interviewees have either said that they haven't been given any formal instruction or that they have been explicitly instructed to use either the impersonal form or the authorial "we":

"Yes, I have been explicitly taught to write like that... I was explicitly told to avoid the first person singular pronoun when I write a research article. They said, never 'I'; if you have to use the first person pronoun, use 'we'." (I.Z., English Department)

"I was never given any formal guidance, not even as a doctoral candidate. I went about it intuitively." (D.D., French Department)

"When I wrote my first research article in the first person singular, my mentor at the Institute explained to me that using the first person singular in research article was considered rude. She instructed me to use "we" instead. I felt as if I made myself seem more important than I was by referring to myself as "we", but my mentor assured me it was not so.... Now when I instruct my younger colleagues how to write, I tell them what I was told when I began writing.“ (K.D., Croatian Department)

"I was explicitly instructed to use the impersonal form; to be more precise, the editor of a journal required that I use the impersonal form. There are different opinions on that in Croatian academic community - I once instructed a student to use the impersonal form in his graduation thesis and another professor who was member of the defense committee told me that there was no need to do so. He then sent me a dozen of examples of articles written in English in which the first person form was used.“ (S.L.U., Croatian Department)

Two of our interviewees have also been editors of journals in linguistics. They have expressed extremely polarized views on the choice of personal perspective in RAs and on the role of journal editors in that respect:

"As journal editor I do not allow my authors to use the personal form." (Z.J., Croatian Department)

"The two journals I edited didn't have a strict editorial policy in terms of the choice of authorial perspective. I can't remember that we had any doubts or interventions in that respect. The authors of our contributions usually used either impersonal forms or the first person plural.... I believe there is a convention in Croatian which holds that writing in the first person singular is „rude“. Now, I don't see why that should be so when on the contrary, you should stand behind what you write, if you're a single author. It always seemed a bit two-faced to me - you are responsible for what you wrote and at the same time you cannot say „I've done this or that. I believe it's simply a convention." (V.M., Phonetics Department)

Our interviewees account for their choice of impersonal structures in various ways, ranging from their presumptions of the conventions of RA writing to much more personal ideas of propriety and their own personal perceptions of themselves and their place in the disciplinary community.

"I do not feel confident enough in my professional skin to use the first person singular." (S.L.U., Croatian Department)

"It is more appropriate within the discourse of the research article to exclude yourself as a person, it seems a bit presumptuous to me to emphasize my own role.(V.J, English Department)

"I think about the choice of perspective, I avoid using "I" so that I don't sound pretentious, it's more that than in order to protect myself from criticism; even when I feel the need to say something from my own personal perspective, I tend to wiggle out of using „I“'. Perhaps I sometimes slip into using ,we“, but I generally go for the passive or some other impersonal construction, even when I mean „I“. (D.K., English Department)

All our interviewees read RAs in English and most of them have also published their articles in English. All of them exhibit an awareness of the first person singular being used more frequently in English than in Croatian RAs. As for their authorial behavior when writing in another language, they seem to stick to their acquired authorial style regardless of the language they write in:

"When I write in English I use impersonal constructions the passive or perhaps "one" rather than first-person pronouns, the same as I do in Croatian - I want to create distance and not assert myself." (V.J., English Department)

"I've written most of my work in French. But even when I write in Croatian, I am heavily influenced by French conventions and I tend to use the authorial "we", which is customary in the French academic discourse." (D.D.B., French Department)

„As an author, I believe I behave in the same way regardless of whether I write in Croatian, Italian or English. (V.D., Italian Department)

Having compared the RAs in the corpus to the authors' claims about their preferred style of writing, we found a high degree of congruity between the authors' perception of their behavior and their actual behavior. For example, the author of RA 1 claims to prefer impersonal forms, the author of RA 8 says that she uses either impersonal forms or the first person plural, while the author of RA 7 perceives herself as predominantly using the first person plural under the 
influence of French academic writing conventions, all of which is displayed in Table 3. This further supports our belief that the choice of perspective in the RA is a conscious and deliberate authorial decision.

\section{Conclusions}

The findings of the quantitative analysis show differences in the frequency of the use of FPP. In the English corpus FPSg pronouns are used considerably more frequently than in the Croatian corpus (221 occurrences in the English corpus vs. 31 occurrences in the Croatian corpus). With regard to the use of FPPl references, we could not observe any difference in the frequency of their inclusive and exclusive references in the Croatian corpus (121 occurrences of the exclusive reference and 122 occurrences of inclusive reference). On the other hand, in the English corpus, a clear preference for the inclusive reference is observed: the English corpus comprises only 5 occurrences of FPPl pronouns with exclusive reference compared to 176 occurrences of FPPl with inclusive reference.

Findings of the analysis of discourse functions performed by FPPs show that in both corpora they are very frequently used multifunctionally and that the discourse functions they perform are directly related to the part of the RA in which they appear. In the English corpus, FPSg pronouns occur both in lower-risk discourse functions (acknowledging other people's or institutions' contributions to the research, explaining the experimental procedure and methodology, etc.) and higher-risk discourse functions (making a claim, stressing one's own contribution). However, it should be noted that in the English corpus higher-risk discourse functions are performed exclusively by FPSg pronouns. As opposed to that, higher-risk discourse functions in the Croatian corpus tend to be framed in the FPPl form.

To conclude, the findings of the quantitative analysis point out two main differences between the practices of the use of FPPs in the two corpora: first, the frequency of the use of FPSg pronouns is significantly lower in the Croatian corpus than in the English corpus; and second, FPPl pronouns with exclusive reference in the Croatian corpus and FPSg pronouns in the English corpus seem to be functional equivalents in higher-risk discourse functions.

Findings from interviews show that the interviewed members of the Croatian scientific community have strong preferences for the use of impersonal forms (the passive voice, "one"). With regard to this, their perception of their own discourse practices complies with the data obtained by textual analysis. This choice is justified by the belief that impersonal forms are "more objective" and that they are in line with the conventions of academic writing in Croatia. Some of the interviewees were explicitly instructed to use the impersonal form in their writing and to avoid "I" as being rude and inappropriate for academic discourse. In this way, the data obtained from interviews clearly point out to the existence of conventions shared by the members of Croatian science community. Also, some of our interviewees exhibit an awareness of adopting different conventions under the influence of other languages or other national disciplinary communities. For example, interviewee who mostly uses authorial "we" in her writing claims to have been strongly influenced by the conventions of academic writing in French, which she acquired owing to her professional initiation and specialization.

To conclude, our findings indicate that the choice of authorial perspective in the texts of RAs in Croatian is a deliberate personal authorial decision, based on the author's awareness of the practice and conventions within their disciplinary community, but also on the author's personality, their own ideas of propriety and of their place within the disciplinary community. The findings of our research, therefore, concur with the nowadays widely accepted view that RA writing is a dynamic social activity in which, as in any other social activity, the individual's choice between humility and assertiveness depends both on the cultural conventions of the community and the status of the individual within that community.

\section{REFERENCES}

[1] Hyland, K. Humble servants of the discipline? Self-mention in research articles. English for Specific Purposes. 2001; 20: 207-226.

[2] Hyland, K. Authority and invisibility: Authorial identity in academic writing. Journal of Pragmatics. 2002; 34 (8): 1091-1112.

[3] Hyland, K. Options of identity in academic writing. ELT Journal. 2002; 56 (4): 351-358.

[4] Hyland, K. Disciplines and discourses: social interactions in the construction of knowledge. In Starke-Meyerring, D., Paré, A., Artemeva, N., Horne, M. and Yousoubova L., editors. Writing in Knowledge Societies. West Lafayette, IN, U.S.A.: Parlor Press and the WAC Clearinghous; 2011. p. 193-214.

[5] Vassileva, I. Who am I/who are we in academic writing? A contrastive analysis of authorial presence in English, German, French, Russian and Bulgarian. International Journal of Applied Linguistic. 1998; 8 (2): 163-190.

[6] Kuo, C-H. „The use of personal pronouns: Role relationships in scientific journal articles. English for Specific Purposes. 1999; 18 (2): 121-138.

[7] Tang, R., John, S. The 'I' in identity: Exploring writer identity in student academic writing through first person pronoun. English for Specific Purposes. 1999; 18(S1): 23-39.

[8] Harwood, N. 'We Do Not Seem to Have a Theory ... The Theory I Present Here Attempts to Fill This Gap': Inclusive and Exclusive Pronouns in Academic Writing. Applied Linguistics. 2005; 26 (3): 343-375.

[9] Mur Dueñas, P. 'I/we focus on...': A cross-cultural analysis of self-mentions in business management research articles. Journal of English for Academic Purposes. 2007; 6: 143-162. 
[10] Molino, A. Personal and impersonal authorial references: A contrastive study of English and Italian Linguistics research articles. Journal of English for Academic Purposes. 2010; 9: 86-101.

[11] Ivanic, R., Simpson, J. Who's Who in Academic Writing?. In Fairclough, N., editor. Critical Language Awareness,. Harlow: Longman; 1992.

[12] Ivanic, Roz. Writing and identity: The discoursal construction of identity in academic writing. Amsterdam: Benjamins; 1998.

[13] Brown, Penelope, Levinson, Stephen C. Universals in language usage: Politeness phenomena. In Goody, Esther N., editor. Questions and Politeness. Cambridge: Cambridge University Press; 1978, p. 56-289.

[14] Thompson, G., Thetela, P. The sound of one hand clapping: The management of interaction in written discourse. Text. 1995; 15(1): 103-127.

[15] Latour, B. Science in Action: How to Follow Scientists and Engineers through Society. Milton Keynes: Open University Press; 1987.

[16] Swales, J. M. Genre Analysis: English in academic and research settings. Cambridge: Cambridge University Press; 1990. 